\title{
Uji Sitotoksisitas Ekstrak Metanol Daun Sisik Naga (Drymoglossum piloselloides Presl.) terhadap Sel Leukemia P388
}

\section{Anwar Sahida*, Dingse Pandiangana, Parluhutan Siahaana, Marhaenus J. Rumondora}

aJurusan Biologi, FMIPA, Unsrat, Manado

KATA KUNCI

Drymoglossum piloselloides

Leukemia P388

Uji MTT

Sitotoksisitas

\begin{tabular}{l}
\hline K E Y W O R D S \\
\hline Drymoglossum piloselloides \\
Leukemia P388 \\
MTT assay \\
Cytotoxicity
\end{tabular}

\begin{tabular}{l}
\hline AVAILABLE ONLINE \\
\hline 19 Oktober 2013 \\
\hline
\end{tabular}

A B S T R A K
Penelitian mengenai uji sitotoksisitas ekstrak metanol daun sisik
naga (Drymoglossum piloselloides Presl.) terhadap sel leukemia P388
telah dilakukan. Penelitian ini bertujuan untuk mengetahui sitotoksisitas
ekstrak metanol daun sisik naga terhadap sel leukemia P388
berdasarkan penghambatan pertumbuhan sel 50\% (IC50). Metoda yang
dilakukan menggunakan uji MTT (Microculture Tetrazolium Technique)
pada sel kanker leukemia P388. Sel dikultur menggunakan media RPMI
(Roswell Park Memorial Institute). Pertumbuhan sel diukur melalui
absorbansi formazan pada panjang gelombang 540 nm pada berbagai
konsentrasi dari 0,1 $\mu$ g/mL sampai $100 \mu g / m L$ ekstrak sampel. IC50
ditentukan dengan persamaan logaritma antara nilai absorbansi dengan
konsentrasi ekstrak. Pengolahan data digunakan program Originlab 9.0
32-bit (Originlab Corporation USA). Hasil penelitian menunjukkan bahwa
ekstrak metanol daun sisik naga memiliki efek sitotoksik terhadap sel
leukemia P388 yang ditunjukkan dengan penghambatan pertumbuhan sel
leukemia sebanyak $50 \%$ adalah $19,32 \mu g / m L$.
A B S T R A C T

The research about cytotoxicity assay of sisik naga (Drymoglossum piloselloides Presl.) leaf methanol extract on leukemia cells P388 has been done. This study aimed to determine the cytotoxicity of the methanol extract of sisik naga leaf against leukemia cells P388 based on the inhibition of $50 \%$ growth $\left(\mathrm{IC}_{50}\right)$. The MTT (Microculture Tetrazolium Technique) test was used in this experiment. Leukemia cells were cultured on RPMI (Roswell Park Memorial Institute) medium. The cell growth was determined by measuring the formazan absorbance in variation of concentration $0,1 \mu \mathrm{g} / \mathrm{mL}$ to $100 \mu \mathrm{g} / \mathrm{mL}$ of sample extract at $540 \mathrm{~nm}$. $\mathrm{IC}_{50}$ determined by logarithmic equation of absorbance values with concentration of extract. Data analysis used the program Originlab 9.032 bit (Originlab Corporation USA). The result showed that methanol extract of sisik naga leaf had cytotoxic effects against leukemia cells and inhibition of $50 \%$ leukemia cell growth was $19.32 \mu \mathrm{g} / \mathrm{mL}$.

\section{Pendahuluan}

Indonesia merupakan negara yang kaya akan keanekaragaman hayati, termasuk di dalamnya tumbuhan obat. Salah satu kekayaan keanekaragaman jenis tumbuhan obat adalah Drymoglossum piloselloides Persl atau sisik naga.
Tumbuhan D. piloselloides adalah salah satu tumbuhan yang tumbuh dan tersebar secara liar di seluruh daerah Asia tropik dan memiliki banyak nama tergantung pada daerah tempat tumbuh (Fatimah, 2009). D. piloselloides merupakan tumbuhan epifit (tumbuh menempel pada tumbuhan lain), tetapi bukan parasit karena dapat

*Corresponding author: Jurusan Biologi FMIPA UNSRAT, Jl. Kampus Unsrat, Manado, Indonesia 95115; Email address: anwar_sahid@yahoo.com

Published by FMIPA UNSRAT (2013) 
membuat makanan sendiri. Bentuk batangnya menjalar dan akarnya melekat kuat pada batang atau pohon yang ditumpangi serta memiliki daun berbentuk seperti sisik naga berwarna hijau tua (van Stennis, 2006).

Tumbuhan D. piloselloides mengandung senyawa flavonoid, tanin, steroid atau triterpenoid, minyak atsiri dan glikosida yang diduga berpotensi sebagai antikanker (Fatimah, 2009; Dalimunthe dan Poppy, 2011). Kanker merupakan penyakit mematikan yang sulit diobati dan penyebab utama kematian diseluruh dunia. Peningkatan angka kejadian kanker yang pesat dan belum adanya terapi yang dianggap tepat untuk mengatasinya memicu masyarakat pada umumnya dan peneliti pada khususnya untuk mengeksplorasi bahanbahan alam yang dianggap potensial sebagai alternatif agen antikanker. Dari hasil penelitian yang telah dilakukan secara empiris tumbuhan ini digunakan sebagai obat kanker payudara (Dalimartha, 2005). Tumbuhan ini di Indonesia melimpah dan dapat ditemukan pada batang, cabang pohon-pohon yang sudah tua, besar dan perdu (van Stennis, 2006). Demikian halnya di Sulawesi Utara, tumbuhan sisik naga ini dari pengamatan langsung sangat banyak ditemukan yang tumbuh menempel pada pohon-pohon seperti pohon angsana, mangga, mahoni, flamboyan, ketapang, palma, nangka, kerai payung dan lain sebagainya.

Tumbuhan obat tradisional banyak yang belum diteliti secara ilmiah, termasuk yang berpotensi sebagai antikanker. Sebagian besar tumbuhan tersebut digunakan sebagai obat, hanya berdasarkan pengalaman masyarakat sehari-hari. Pemanfaatan tumbuhan sebagai obat tradisional yang terstandar perlu didasarkan pada hasil penelitian-penelitian ilmiah. Sampai saat ini uji antikanker yang banyak dilakukan adalah menggunakan mencit yang relatif lama dan keberhasilannya rendah. Tetapi sekarang ini telah ada teknik kultur in vitro, yaitu suatu teknik untuk mengisolasi secara aseptik dalam tabung dan ditumbuhkan dalam media buatan (Pandiangan, 2011). Beberapa penelitian yang menggunakan teknik kultur in vitro antara lain Heti (2008) yang menguji sitotoksik ekstrak etanol $70 \%$ herba sisik naga terhadap sel T47D. Pandiangan (2011) menguji aktivitas antikanker senyawa katarantin yang diperoleh dari kalus Catharanthus roseus terhadap sel leukemia P388; Fitrya dan Lenny (2009) menguji aktivitas sifat antikanker dari senyawa flavonoid yang berasal pada akar tumbuhan tunjuk langit (Helmynthostachis zeylanica Linn.) terhadap sel murine P388, Abdillah (2006) menguji antiproliferasi ekstrak air daun sisik naga terhadap sel lestari Tumor HeLa.

Pemanfaatan tumbuhan sisik naga untuk dijadikan sebagai obat perlu di teliti dan dikembangkan secara ilmiah. Oleh karena itu, perlu dilakukan penelitian ilmiah tentang potensi tumbuhan tersebut terhadap sel kanker. Penelitian uji sitotoksisitas ekstrak metanol daun sisik naga terhadap sel leukemia P388 belum ada yang melaporkan. Di samping itu leukemia merupakan penyebab kematian yang cukup tinggi pada anakanak meskipun penyebabnya belum diketahui secara pasti (Anonim, 2006). Ekstraksi senyawa bioaktif daun sisik naga telah dilakukan dengan menggunakan etanol 70\% (Heti 2008), aseton (Suwarni 2009), air (Wulandari 2013, Abdillah 2006), tetapi ekstraksi senyawa bioaktif daun sisik naga yang menggunakan metanol belum pernah dilaporkan. Santosa (1995) dalam Lazuardi (2006) berasumsi bahwa metanol merupakan salah satu jenis pelarut organik kuat serta mampu melarutkan unsur-unsur bioaktif (termasuk antikanker) pada umumnya tumbuhan obat. Oleh karena itu penelitian ini dilakukan untuk menguji sitotoksisitas ekstrak metanol daun sisik naga terhadap sel leukemia P388 berdasarkan penghambatan pertumbuhan sel kanker leukemia P388 50\% (IC50) dari ekstrak metanol daun sisik naga.

\section{Metodologi}

\subsection{Tempat dan Waktu Penelitian}

Penelitian ini dilaksanakan di Laboratorium Konservasi dan Ekologi Jurusan Biologi Fakultas Matematika dan IImu Pengetahuan Alam Universitas Sam Ratulangi Manado untuk pembuatan ekstrak dan untuk uji sitotoksisitas ekstrak metanol daun sisik naga dilakukan di Laboratorium Kimia Organik Bahan Alam (KOBA) ITB Bandung. Waktu penelitian dilakukan pada bulan April-Mei 2013.

\subsection{Alat dan Bahan}

Alat-alat yang digunakan dalam penelitian ini adalah timbangan kasar, timbangan digital, oven, wadah plastik, ayakan, blender, toples kaca, gelas ukur $250 \mathrm{ml}$ dan $1000 \mathrm{ml}$, labu Erlenmeyer $250 \mathrm{ml}$ dan $500 \mathrm{ml}$, corong, batang pengaduk, aluminium foil, pisau, gunting, talenan, kain lap, tissu, cawan petri, kertas label, tabung eppendorf, kertas saring whatman $43(15.0 \mathrm{~cm})$, kamera digital. Bahanbahan yang digunakan yaitu daun tumbuhan sisik naga segar, metanol analitis, sel leukemia P388.

\subsection{Prosedur Penelitian}

\subsubsection{Pengambilan Sampel (Koleksi)}

Pada studi pendahuluan ini sampel yang digunakan adalah daun sisik naga yang steril atau daun mandul (berbentuk bulat) dan berwarna hijau tua yang tumbuh menempel pada batang pohon angsana. Sampel diambil di sekitar Kampus Universitas Sam Ratulangi Manado Propinsi Sulawesi Utara. Pengambilan sampel tumbuhan sisik naga pada pohon angsana dikarenakan tumbuhan tersebut paling banyak ditemukan dibanding pada pohon lain. Penggunaan daun sisik naga steril adalah untuk menghindari agar sampel tidak tercampur dengan spora yang ada pada daun fertil. 
Daun sisik naga kemudian dicuci bersih, ditiriskan dan diiris kecil-kecil, lalu ditimbang sebanyak $1 \mathrm{~kg}$. Hasil penimbangan tersebut dinyatakan sebagai berat basah. Daun tersebut selanjutnya dikeringkan dalam oven pada suhu $45^{\circ} \mathrm{C}$ sampai beratnya konstan (Harbone, 1996). Setelah itu, didinginkan dan kemudian berat kering diukur sehingga dapat ditentukan parameter kadar airnya. Rumus yang digunakan untuk menentukan kadar air sebagai berikut (Abdillah, 2005):

$$
\text { Kadar air }=\frac{X-Y}{X} \times 100 \%
$$

$X=$ berat basah daun (gram)

$\mathrm{Y}=$ berat kering daun (gram)

\subsubsection{Ekstraksi}

Sampel daun yang telah kering, dihaluskan menggunakan blender. Hasil blender diayak dan disaring sebanyak 2 kali sampai didapatkan serbuk halus. Ekstraksi dilakukan secara maserasi yaitu serbuk simplisia ditimbang sebanyak 100 gram direndam dalam stoples kaca dengan penambahan $500 \mathrm{ml}$ metanol analitis. Sampel direndam selama 7 x 24 jam dan setiap 1 x 24 jam dilakukan pengadukan. Hasil rendaman tersebut kemudian disaring menggunakan kertas saring whatman 43 $(15.0 \mathrm{~cm})$. Selanjutnya ekstrak hasil saringan diisikan ke dalam cawan petri dan diuapkan dalam suhu ruang $37^{\circ} \mathrm{C}$ sampai kering. Proses ini dilakukan dengan tujuan untuk mendapatkan ekstrak kasar dari tumbuhan sisik naga (Harbone, 1996). Ekstraksi dilakukan 2 kali. Ekstrak kering kemudian digunakan pada uji sitotoksisitas pada tahap berikutnya.

\subsubsection{Uji Sitotoksisitas}

Persiapan buffer dan media serta sterilisasi dilakukan sesuai dengan yang dilakukan oleh Laboratorium Kimia Organik Bahan Alam (KOBA) ITB. Uji sitotoksisitas dilakukan dengan mengunakan sel leukemia P388. Sel dipelihara dalam botol kultur pada media RPMI (Roswell Park Memorial Institute) dalam "multiwell plate". Pengkulturan sel dilakukan dalam kondisi steril. Kultur sel dipelihara sampai memenuhi 80\% substrat. Subkultur dilakukan mengikuti metoda yang digunakan Alley (1988) dalam Pandiangan (2008).

Kultur sel yang telah memenuhi $80 \%$ substrat dissosiasi. Disosiasi dilakukan dengan cara pencucian kultur sel dengan FBS (Fetal Bovine Serum) sebanyak 3 kali, lalu dibilas dengan EDTA $0,02 \%$ dan diberi tripsin $0,25 \%$. Sel diinkubasi pada suhu $370 \mathrm{C}$ dalam inkubator $\mathrm{CO}_{2}$ selama 2 menit sampai sel lepas dari substrat botol kultur. Suspensi sel ditambah dengan medium pemeliharaan yang mengandung 5\% FBS (Fetal Bovine Serum) dengan perbandingan volume 1:1. Sel disentrifugasi dengan kecepatan 1000 rpm selama 5 menit. Supernatan hasil sentrifugasi dibuang dan pelet sel diberi medium pemeliharaan. Sel hidup dihitung menggunakan hemositometer tipe Improved Neubauer dengan rumus perhitungan menurut Freshney (2000).

Ekstrak metanol kering sebanyak $1 \mathrm{mg}$ ditambahkan dengan $1 \mathrm{~mL}$ DMSO (Dimethyl sulfoxide) sampai larut sebagai stok larutan ekstrak untuk membuat variasi konsentrasi. Kemudian dibuat variasi konsentrasi ekstrak mulai dari 0,1 $\mu \mathrm{g} / \mathrm{mL}, 0,3 \mu \mathrm{g} / \mathrm{mL}, 1 \mu \mathrm{g} / \mathrm{mL}, 3 \mu \mathrm{g} / \mathrm{mL}, 10 \mu \mathrm{g} / \mathrm{mL}$, $30 \mu \mathrm{g} / \mathrm{mL}$, dan $100 \mu \mathrm{g} / \mathrm{mL}$. Masing-masing ekstrak dimasukkan ke kultur sel leukemia P388. Sel yang telah diberi ekstrak dipelihara pada medium dasar yang mengandung $2 \%$ FBS dan diinkubasi selama 24 jam agar sel melekat pada substrat (KOBA ITB). Aktivitas pertumbuhan sel setelah perlakuan diukur dengan pemberian larutan MTT (3-(4,5-dimetiltiazol2-il)-2,5-difeniltetrazolium bromid). Mediumnya dibuang dan diberi $200 \mu \mathrm{L}$ medium dasar yang mengandung 2\% FBS (Fetal Bovine Serum) dan 50 $\mu \mathrm{L}$ larutan MTT untuk setiap sumur. Sel diberi MTT untuk mengukur efek sitotoksik sampel. Sel diinkubasi selama 4 jam pada suhu $37^{\circ} \mathrm{C}$ dengan kondisi gelap. Setelah itu, medium dibuang dan diberi $200 \mu \mathrm{L}$ DMSO (Dimethyl sulfoxide) dan $25 \mu \mathrm{L}$ bufer glisin. Intensitas absorbansi warna diukur dengan menggunakan microplate spectrophotometer (Bio Rad) pada panjang gelombang $540 \mathrm{~nm}$. Intensitas absorbansi warna dibuat untuk mencari nilai Inhibition concentration sebanyak 50\% (IC 50 ) dari ekstrak daun sisik naga. Pengukuran dilakukan 3 kali dari tiap konsentrasi, masing-masing konsentrasi diulang 3 kali (KOBA ITB).

\subsection{Analisis Data}

$\mathrm{IC}_{50}$ (Inhibition Concentration50) ditentukan melalui persamaan logaritma dari rata-rata absorbansi 3 ulangan data setiap konsentrasi dengan konsentrasi ekstrak sampel. Analisis data digunakan program Originlab 9.0 32-bit (Originlab Corporation USA). Melalui program tersebut diperoleh persamaan logaritma yang mengandung penghambatan pertumbuhan sel 50\% (IC50) pada konsentrasi tertentu sesuai data absorbansi hasil pengukuran pada konsentrasi 0,1 sampai 100 $\mu g / m L$.

\section{Hasil dan Pembahasan \\ 3.1. Ekstrak Daun Sisik Naga (D. piloselloides Persl.)}

Pembuatan ekstrak daun sisik naga diawali dengan pengukuran kadar air sampel. Pentingnya pengukuran kadar air yang terkandung dalam sampel yang akan diuji karena dapat berpengaruh pada proses ekstraksi (Ketaren, 1985 dalam Tangapo, 2005). Berat kering sampel daun sisik naga yang diperoleh ialah 212 gram. Kadar air daun sisik naga (D. piloselloides) cukup besar yaitu sekitar 79\%. Besarnya kadar air yang terdapat dalam daun sisik naga (D. piloselloides) disebabkan tumbuhan sisik naga memiliki daun tebal berdaging 
dan berair (van Stennis, 2006). Kadar air ini sebagai informasi ilmiah yang diharapkan dapat dimanfaatkan pada pengolahan tumbuhan sisik naga sebagai ramuan tradisional.

Hasil uji golongan kimia terbukti bahwa tumbuhan sisik naga memiliki kandungan kimia berupa minyak atsiri, sterol atau triterpen, fenol, flavonoid, tanin, dan glikosida (Fatimah, 2009; Dalimunthe dan Poppy, 2011). Perendaman sampel dalam pelarut akan mengakibatkan dinding sel daun sisik naga akan keluar dan terlarut dalam pelarut yang digunakan (Haryadi, 2012). Sampel daun yang telah direndam menghasilkan ekstrak cair sebanyak $300 \mathrm{ml}$ setelah disaring. Setelah ekstrak cair diuapkan diperoleh ekstrak kering sebanyak 5,18 gram dan rendemennya sebesar $5 \%$. Rendemen adalah perbandingan antara ekstrak yang diperoleh dengan simplisia awal (Abdillah, 2006).

\subsection{Uji Sitotoksisitas}

Uji sitotoksisitas dalam penelitian ini dilakukan untuk mengetahui efek sitotoksik ekstrak metanol daun sisik naga terhadap sel kanker leukemia P388 secara in vitro. Metode uji yang digunakan adalah metode MTT (microculture tetrazolium technique). Pereaksi MTT yang digunakan merupakan garam tetrazolium yang dapat dipecah menjadi kristal formazan oleh sistem suksinat tetrazolium reduktase yang terdapat dalam jalur respirasi pada mitokondria yang aktif pada sel yang masih hidup. Kristal formazan ini memberi warna ungu dan tidak larut dalam air yang dapat dibaca absorbansinya dengan menggunakan microplate spectrophotometer pada panjang gelombang 540 $\mathrm{nm}$ (CCRC, 2012). Namun pada pengamatan di atas microplate spectrophotometer nampak warna ungu berpendar, pada gambar terlihat titik putih (Gambar 1a). Jika absorbansi semakin besar semakin besar, maka jumlah sel hidup semakin banyak).

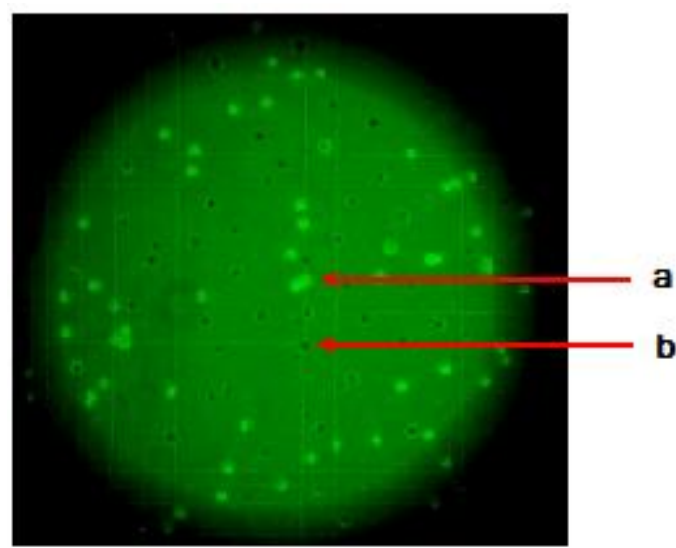

Gambar 1 - Salah satu penampakan morfologi sel kanker leukemia P388 setelah pemberian MTT (a) sel yang hidup (titik putih), (b) sel yang mati (titik hitam).

Morfologi sel kanker leukemia P388 diamati dan dihitung menggunakan microplate spectrophotometer pada panjang gelombang 540 $\mathrm{nm}$. Pengamatan dilakukan setelah pemberian larutan MTT (3-(4,5-dimetiltiazol-2-il)-2,5difeniltetrazolium bromid). Gambar 1 merupakan salah satu penampakan morfologi dari sampel yang di uji. Hasil pengamatan menunjukkan bahwa sel yang hidup nampak ungu berpendar tetapi pada gambar terlihat titik putih, sedangkan sel yang mati nampak bulatan bening tetapi pada gambar terlihat titik hitam.

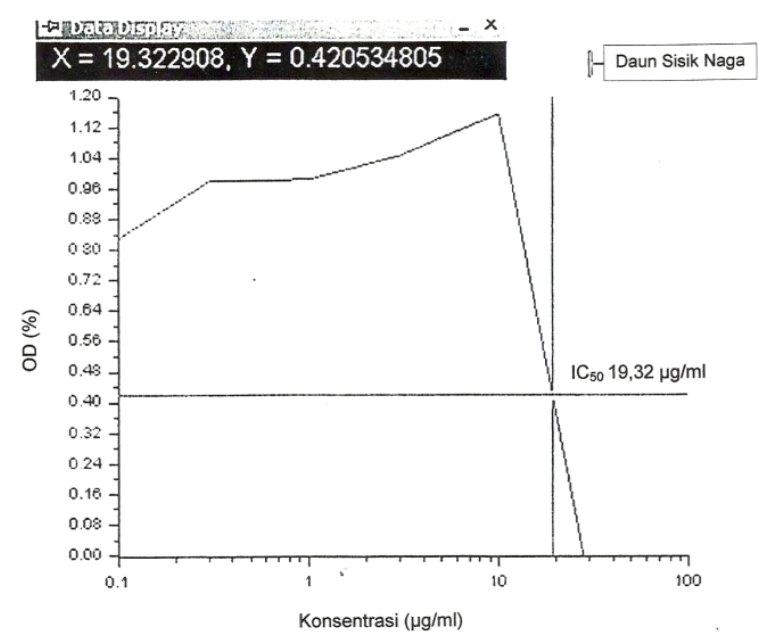

Gambar 2 - Grafik persamaan logaritma antara rata-rata absorbansi dengan konsentrasi ekstrak dalam menentukan nilai $I_{50}$ ekstrak metanol daun sisik naga ( $D$. piloselloides) terhadap sel leukemia P388.

Hasil analisis data diperoleh nilai $I_{50}$ ekstrak metanol daun sisik naga terhadap sel kanker leukemia P388 seperti pada Gambar 2. Hasilnya menunjukkan bahwa ekstrak metanol daun sisik naga memiliki efek sitotoksik terhadap sel leukemia P388 dengan nilai IC 50 sebesar $19,32 \mu \mathrm{g} / \mathrm{mL}$. Hal ini menunjukkan bahwa pada konsentrasi 19,32 $\mu \mathrm{g} / \mathrm{mL}$ ekstrak metanol daun sisik naga mampu menghambat pertumbuhan sel kanker leukemia P388 sebanyak 50\%.

Menurut Cho et al., (1998) dalam Fitrya dan Lenny (2009) kuatnya suatu ekstrak dianggap toksik terhadap sel kanker dinyatakan sebagai berikut : kategori sangat aktif jika nilai $I_{50} 5 \mu \mathrm{g} / \mathrm{mL}$, kategori aktif jika nilai IC $505-10 \mu \mathrm{g} / \mathrm{mL}$, kategori sedang jika nilai $\mathrm{IC}_{50} 11-30 \mu \mathrm{g} / \mathrm{mL}$ dan kategori tidak aktif jika nilai $\mathrm{IC}_{50}>30 \mu \mathrm{g} / \mathrm{mL}$.

Efek sitotoksik ekstrak metanol daun sisik naga terhadap sel leukemia P388 dengan nilai IC 50 sebesar 19,32 $\mathrm{gg} / \mathrm{mL}$ menurut Cho et al. (1998) dalam Fitrya dan Anwar (2009) tergolong senyawa aktif. Suffnes dan Pezzuto (1991) dalam Kartika (2013) menyatakan bahwa suatu senyawa bersifat sitotoksik bila aktivitas terhadap sel uji memiliki nilai $\mathrm{IC}_{50}<20 \mu \mathrm{g} / \mathrm{mL}$ untuk suatu ekstrak, dan $\mathrm{IC}_{50}<4$ $\mu \mathrm{g} / \mathrm{mL}$ untuk senyawa murni. Hal ini menguatkan ekstrak metanol daun sisik naga memiliki aktivitas antikanker terhadap sel leukemia P388. Aktivitas antikanker tersebut kemungkinan disebabkan oleh 
adanya senyawa metabolit sekunder yang terkandung pada tumbuhan sisik naga yaitu flavonoid, saponin, tanin dan steroid yang kemungkinan dapat berperan sebagai antikanker (Abdillah, 2006; Wulandari et al., 2013).

Menurut Markham (1988) dalam Abdillah (2006) menyatakan bahwa senyawa flavonoid merupakan senyawa polar sehingga dapat larut dalam pelarut polar seperti metanol, etanol, aseton, DMSO (dimetil sulfoksida), DMF (dimetil forfamida) dan air. Flavonoid bersifat sitotoksik dan dapat memacu apoptosis melalui beberapa mekanisme antara lain penghambatan aktivitas DNA topoisomerase $\mathrm{I} / \mathrm{II}$, modulasi signaling pathways, penurunan ekspresi gen $\mathrm{Bcl}-2$ dan $\mathrm{Bcl}-\mathrm{xl}$, peningkatkan ekspresi gen Bax dan Bak serta aktivasi endonuklease (Ren et al., 2003).

Senyawa steroid berfungsi untuk pertumbuhan dan diferensiasi sel dengan mengikat protein (Chory, 2005). Steroid bertindak pada penghambatan DNA topoisomerase II untuk mencegah siklus sel kanker (Afandi, 2006 dalam Abdillah, 2006). Terdapat juga senyawa tanin yang merupakan senyawa polifenol kelompok flavonoid yang berfungsi sebagai antikanker, antioksidan kuat, dan antiperadangan (Olivia et al., 2004 dalam Abdillah, 2006). Senyawa tanin dapat juga meningkatkan protein p27 yang menghambat siklus sel (Nam et al., 2001).

Heti (2008) telah menguji manfaat tumbuhan ini sebagai antikanker secara in vitro terhadap sel T47D (sel payudara). Hasil penelitiannya menunjukkan bahwa ekstrak etanol $70 \%$ herba sisik naga tidak mempunyai efek sitotoksik terhadap sel T47D. Suwarni (2009) menguji efek sitotoksik dan antiproliferasi ekstrak aseton daun sisik naga terhadap sel SiHa. Hasil penelitiannya menunjukkan bahwa ekstrak daun sisik naga dengan pelarut aseton memiliki aktivitas sitotoksik (penghambatan sel kanker) dan antiproliferasi (mencegah pembelahan) terhadap sel $\mathrm{SiHa}$ (sel kanker rahim). Demikian juga Widyanti (2011) dalam Wulandari et al. (2013) menguji ekstrak air daun sisik naga terhadap sel lestari Tumor MCM-B2 secara in vitro. Hasil penelitiannya menunjukkan bahwa ekstrak air daun sisik naga memiliki aktivitas antiproliferasi (mencegah pembelahan) terhadap sel lestari MCMB2 (sel kanker payudara) sebesar 59,09\% pada konsentrasi 1050 ppm. Abdillah (2006) menguji ekstrak air daun sisik naga terhadap sel lestari Tumor HeLa secara in vitro. Hasilnya menunjukkan bahwa terdapat aktivitas antiproliferasi ekstrak air daun sisik naga terhadap sel lestari tumor HeLa dimana aktivitas tertinggi dicapai pada konsentrasi 1050 ppm yaitu sebesar 84,46\%.

Data yang dihasilkan melalui penelitian ini menunjukkan adanya efek sitotoksik dari ekstrak metanol daun sisik naga terhadap sel leukemia P388. Hal ini juga menambah data khasiat dari bahan alam yang memiliki efek sitotoksik terhadap sel kanker leukemia. Perlu adanya penelitian lebih lanjut untuk menjelaskan mekanisme terjadinya efek sitotoksik dari ekstrak metanol daun sisik naga terhadap sel leukemia P388, menelusuri dan mengisolasi senyawa aktif pada ekstrak metanol dari daun sisik naga. Demikian juga untuk penerapannya di masyarakat masih perlu kajian yang lebih lanjut.

\section{Kesimpulan}

Studi pendahuluan ini menunjukkan bahwa ekstrak metanol daun sisik naga (D. piloselloides) memiliki efek sitotoksik terhadap sel leukemia P388 berdasarkan nilai penghambatan pertumbuhan sel leukemia P388 sebanyak 50\% (IC50) adalah 19,32 $\mu \mathrm{g} / \mathrm{mL}$ ekstrak sampel. Untuk Memastikan potensi tumbuhan sisik naga sebagai obat anti leukemia dan kanker lainnya masih perlu dilakukan penelitian lebih lanjut yang lebih terperinci.

\section{Daftar Pustaka}

Abdillah, A. Aktivitas Antiproliferasi Ekstrak Air Daun Sisik Naga (Pyrrosia nummularifolia (Sw.) Ching) terhadap Sel Lestari Tumor HeLa secara In Vitro. [Skripsi]. Fakultas Kedokteran Hewan IPB, Bogor. 2006.

Anonim. http://www.depkes.go.id/index.php/berita/ press-release/975-waspadai-gejala-kankerpada- anak.html. 2006. Diakses 15 Juni 2013.

CCRC (Cancer Chemopreventation Research Center). Prosedur Tetap Uji Sitotoksik Metode MTT. http: //www.ccrc.farmasi.ugm.ac.id/wp-content/ uploads/03.010.-Sitotoksik.pdf.2012. Diakses 13 Mei 2013.

Chory, J. Plant hormon discovery offers potentially increased crop yield. http://www.salk.edu/ news/releases. 2005. Diakses 22 Juli 2013.

Dalimartha, S. Tanaman Obat di Lingkungan Sekitar. Niaga Swadaya, Jakarta. 2005.

Dalimunthe, A; Poppy, A.Z. Uji Aktivitas Antioksidan Ekstrak Etanol Daun Sisik Naga (Drymoglossum piloselloides [L.] Presl.). Prosiding Seminar Nasional. 2011, 303-309.

Fatimah, C. Uji Aktifitas Antituberkulosis Ekstrak Daun Picisan (Drymoglossum piloselloides L.) dibandingkan dengan Rifampisin dan Etambutol terhadap Bakteri Mycobacterium tuberculosis. Kultura. 2009, 10, 1-8.

Fitrya; Lenny, A. Uji Aktivitas Antikanker secara In Vitro dengan Sel Murine P-388 Senyawa Flavonoid dari Fraksi Etilasetat Akar Tumbuhan Tunjuk Langit (Helmynthostachis Zeylanica (Linn) Hook). Jurnal Penelitian Sains. 2009, 12 (1), 1-4.

Freshney, R.I. Culture of Animal Cells : A Manual of Basic Technique, $4^{\text {th }}$ ed. Willey-Liss Inc, Canada. 2000.

Harbone, J.B. Metode Fitokimia, Penuntun Cara Modern Menganalisa Tumbuhan. Penterjemah 
Kosasih P dan Iwang S. Cetakan kedua. ITB, Bandung. 1996.

Heti, D. Uji Sitotoksik Ekstrak Etanol 70\% Herba Sisik Naga (Drymoglossum piloselloides Presl.) terhadap Sel T47D. [Skripsi]. Fakultas Farmasi Universitas Muhammadiyah, Surakarta. 2008.

Kartika, R. Isolasi dan Elusidasi Struktur Kimia Senyawa Bioaktif Antikanker dari Buah Tumbuhan Bawang Hutan (Scorodocarpus borneensis Becc) [Disertasi]. Fakultas Matematika dan IImu Pengetahuan Alam Universitas Sumatera Utara, Medan. 2013.

Lazuardi, M. Aktifitas Antiproliferatif Ekstrak Metanol Daun Benalu Duku (Dendrophtoe sp) terhadap Sel Mieloma secara In vitro. Veterinary Faculty Airlangga University. http://zakki.staf. narotama.ac.id/files/2012/02/aktifitas-anti proliferatif-ekstrak-metanol-daun-benalu-dukuDendrophtoe-sp-terhadap-sel-mieloma-secaraIn-vitro. 2006.

Nam, S; Smith, D.M; Dou, Q.P. Tannic Acid Potently Inhibits Tumor Cell Proteosome Activity Increase p27 and Bax Expression, and Induces G1 Arrest and Apoptosis, Cancer Epidemiology Biomarkers and Prevention. 2001, 10, 10831088.

Pandiangan, D; Esyanti, R; de Queljoe, E. Aktivitas Antikanker Katarantin pada Sel Mouse Mammary Cancer MmT06054. Jurnal IImiah Sains. 2008, 8 (1): 107-113.

Ren, W; Qiao, Z; Wang, H; Zhu, L; Zhang, L. Flavonoids: Promising Anticancer Agents, Medicinal research Reviews. 2003, 23 (4): 519-534.

Suwarni, L. Uji Efek Sitotoksisitas dan Antiproliferatif Ekstrak Aseton Daun Sisik Naga (Drymoglossum piloselloides [L.] Presl.) terhadap Sel SiHa. [Skripsi]. Fakultas Farmasi Universitas Ahmad Dahlan, Yogyakarta. 2009.

Wulandari, E.T.; Elya, B.; Hanani, E.; Pawitan, J.A. In Vitro Antioxidant and Cytotoxicity Activity of Extract and Fraction Pyrrosia piloselloides (L) M.G Price. International Journal of PharmTech Research. 2013, 5 (1): 119-125. 